\title{
Synthesis of Novel Chiral Polymethacrylate Bearing Urethane and 1,1'-Binaphthalene Moieties and Its Chiral Recognition Ability
}

\author{
Yong-Kyung LeE, Kenjiro OnimuRA, Hiromori Tsutsumi, and Tsutomu Oishi ${ }^{\dagger}$ \\ Department of Applied Chemistry and Chemical Engineering, Faculty of Engineering, Yamaguchi University, \\ 2-16-1 Tokiwadai, Ube, Yamaguchi 755-8611, Japan
}

(Received November 24, 2000; Accepted February 27, 2001)

\begin{abstract}
New chiral methacrylate, $(S)$-2-methoxy-1,1'-binaphthyl-2'-( $N$-methacryloyloxyethyl)carbamate (MBiMOC), was synthesized from 2-methacryloyloxyethyl isocyanate and 1,1'-binaphthalene-2,2'-diol. Radical polymerizations of MBiMOC were performed in several solvents to obtain the corresponding chiral polymers. Specific optical rotation of poly(MBiMOC) changed by the measurement temperature, which may be attributed in part to change of conformation caused by hydrogen bonds between urethane segments. From the results of copolymerizations of MBiMOC with styrene and methyl methacrylate, monomer reactivity ratios $\left(r_{1}, r_{2}\right)$ and Alfrey-Price $Q-e$ were determined and chiroptical properties of the copolymers were affected by co-units. Three types of chiral stationary phases (CSPs), poly(MBiMOC)-coated-silica gel (CSP-I), poly(MBiMOC)-bonded-silica gel (CSP-II), and (S)-MeBinol-bonded-silica gel (CSP-III) were prepared from silica gel, MBiMOC, and $(S)$-MeBinol. The CSPs resolved racemates some using $n$-hexane/2propanol as mobile phase for high performance liquid chromatography (HPLC). Difference in chiral resolution ability between CSP-I, CSP-II, and CSP-III was observed, suggesting that the chiral recognition ability of poly(MBiMOC) may be based on the higher-ordered structure of the polymer.
\end{abstract}

KEY WORDS 2-Methacryloyloxyethyl Isocyanate / Radical Polymerization / Monomer Reactivity Ratios / Chiral Stationary Phase / High Performance Liquid Chromatography /

Recently, a wide variety of chiral stationary phases (CSPs) have been developed for the separation of enantiomers by high performance liquid chromatography (HPLC). ${ }^{1}$ Although many kinds of synthetic chiral polymers have been applied to the CSPs, there have been few reports on preparation of CSPs for HPLC from polymethacrylates bearing a chiral pendant group. ${ }^{2}$ The reason may be that low chiral recognition ability of the chiral pendant group used and/or the absence of the stable higher-ordered structure of the polymers. ${ }^{2}$ Only Tamai and Miyano et al. ${ }^{3}$ synthesized optically active polymethacrylates bearing a $1,1^{\prime}$-binaphthalene moiety as pendant group, and investigated on optical resolution ability as a chiral adsorbent for HPLC. However, the chiral recognition ability of the polymers was conferred by mainly interaction between the individual 1,1'binaphthalene units and the racemates. ${ }^{3}$ It is well known that polymethacrylamides bearing a chiral pendant group are served as CSPs with outstanding recognition ability due to conformation controlled by hydrogen bonds between amide groups. Blaschke et al. ${ }^{4}$ and Arlt et $a l .{ }^{5}$ reported the synthesis of many chiral polymethacrylamides from $\alpha$-amino acids and their chiral recognition ability. We reported previously on the synthesis of new chiral polymethacrylates bearing urethane moieties as source of hydrogen bonds from 2methacryloyloxyethyl isocyanate (MOI) and their chiral recognition ability. ${ }^{6}$

MOI is a difunctional monomer with both a reactive isocyanate group and a polymerizable double bond, and is covenient and widely used for crosslinking agents and materials for molecular design of new polymers. ${ }^{7}$ Many kinds of MOI derivatives have been synthesized from several alcohol and amine compounds and polymerized. ${ }^{8}$ MOI is also useful for preparation of macromonomer. ${ }^{9}$ We synthesized and polymerized $N$-substituted maleimide (RMI) macromonomers and examined from the view point of thermal stability of the polymers obtained. ${ }^{10}$ However there have been few reports on synthesis of MOI derivatives bearing an optically active group. Bamford $e t a l .{ }^{11}$ synthesized MOI derivatives from $\alpha$-amino acid and D-glucosamine and examined applications of polymers to blood compatibility. CSP for HPLC was prepared from MOI and cyclodextrin. ${ }^{12}$ To our knowledge, no chiroptical properties of MOI derivatives with optically active groups have been reported. Thus, we lately reported on polymerizations and chiroptical properties of cholesteryl $\quad N$ - (2-methacryloyloxyethyl ) carbamate (ChMOC) ${ }^{13}$

This article describes the synthesis and polymerization of new chiral methacrylate with both an urethane and a $1,1^{\prime}$-binaphthalene moiety. Chiroptical properties of the homopolymer and copolymers with styrene or methyl methacrylate are discussed. CSPs are prepared from silica gel and the chiral polymethacrylate for HPLC and their optical resolution abilities are also investigated.

\section{EXPERIMENTAL}

\section{Materials}

MOI (Showa Denko Co. Ltd.) was purified on distillation under reduced pressure. Styrene (ST) and methyl methacrylate (MMA) were purified by the ordinary methods. ${ }^{14}$ Tetrahydrofuran (THF) and benzene were dried over sodium metal and then used after distillation.

${ }^{\dagger}$ To whom all correspondence should be addressed (Tel: +81-836-85-9281; Fax: +81-836-85-9201; E-mail: oishi@po.cc.yamaguchi-u.ac.jp). 


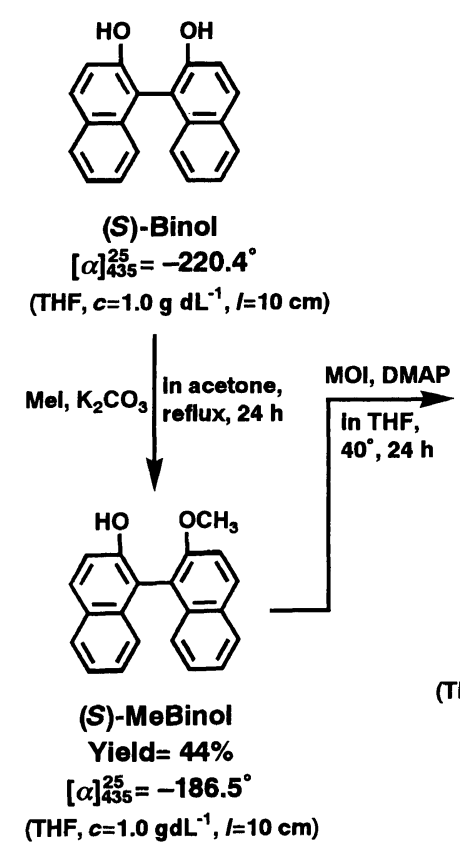

(THF, $c=1.0 \mathrm{gdL}^{-1}, l=10 \mathrm{~cm}$ )

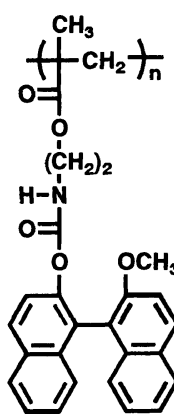

poly(MBiMOC)

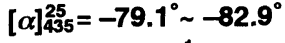

$\left(\mathrm{THF}, c=1.0 \mathrm{~g} \mathrm{dL}^{-1}, l=10 \mathrm{~cm}\right.$ )<smiles>CNCOC(=O)C(C)(C)C</smiles>

Yield $=\mathbf{7 4 \%}$

$[\alpha]_{435}^{25}=-87.8^{\circ}$

(THF, $c=1.0 \mathrm{~g} \mathrm{dL}^{-1}, l=10 \mathrm{~cm}$ )
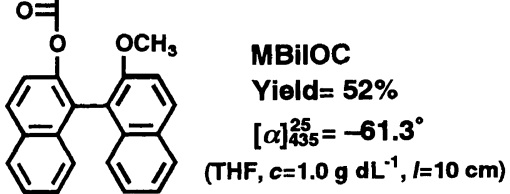

Scheme 1.

$N, N$-Dimethylformamide (DMF), acetone, and chloroform $\left(\mathrm{CHCl}_{3}\right)$ were used after distillation. 2,2'Azobisisobutyronitrile (AIBN) was purified by recrystallization from methanol. Other reagents were used without further purification. Monomer was synthesized, as drawn in Scheme 1.

(S)-2-Methoxy-1,1'-binaphthalene-2'-ol ((S)-MeBinol). To a solution of $(S)-1,1^{\prime}$-binaphthalene-2,2'-diol $((S)$ Binol, $\left.10.0 \mathrm{~g}, 3.5 \times 10^{-2} \mathrm{~mol}\right)$ in acetone $(100 \mathrm{~mL})$ was added potassium carbonate $\left(\mathrm{K}_{2} \mathrm{CO}_{3}, 23.1 \mathrm{~g}, \dot{3} .5 \times 10^{-1}\right.$ mol) and methyl iodide (MeI, $2.18 \mathrm{~mL}, 3.5 \times 10^{-2} \mathrm{~mol}$ ). The reaction mixture was refluxed for $24 \mathrm{~h}$ and then cooled to r.t. The mixture was filtered and the filtrate was evaporated under reduced pressure. To the residue was added dichloromethane $(80 \mathrm{~mL})$, washed with distilled water and brine, dried with anhydrous sodium sulfate, and filtered. After evaporation of the solvent under reduced pressure, the residue was purified by column chromatography on silica gel with chloroform as eluent to afford (S)-MeBinol as colorless crystals: yield $44 \%$; mp $82-84^{\circ} \mathrm{C} ; \quad[\alpha]_{435}^{25}-186.5^{\circ} \quad\left(c=1.0 \mathrm{~g} \mathrm{dL}^{-1}, \quad l=10 \mathrm{~cm}\right.$, THF); ${ }^{1} \mathrm{H}$ NMR ( $\delta$, ppm from tetramethylsilane (TMS) in $\left.\mathrm{CDCl}_{3}\right) 8.08-7.03(\mathrm{~m}, 12 \mathrm{H}$, in binaphthalene group), $4.93(\mathrm{~s}, 1 \mathrm{H}, \mathrm{OH}), 3.81\left(\mathrm{~s}, 3 \mathrm{H}, \mathrm{O}-\mathrm{CH}_{3}\right) ;{ }^{13} \mathrm{C} \mathrm{NMR}(\delta, \mathrm{ppm}$ from TMS in $\mathrm{CDCl}_{3}$ ) 155.97, 151.20, 134.00, 131.05, $129.78,129.40,129.11,128.12,127.31,126.40,124.87$, $124.80,124.15,123.22,117.43,115.26,113.77$ (in binaphthalene group), $56.66\left(\mathrm{O}-\mathrm{CH}_{3}\right)$.

(S) - 2-Methoxy-1, 1'-binaphthyl-2' - (N-methacryloyl oxyethyl)carbamate (MBiMOC). To a mixture solution of $(S)$-MeBinol $\left(2.9 \mathrm{~g}, 9.6 \times 10^{-3} \mathrm{~mol}\right)$ and $N, N$ dimethylpiridine (DMAP, $0.01 \mathrm{~g}, 8.2 \times 10^{-5} \mathrm{~mol}$ ) in THF $(30 \mathrm{~mL})$ was added MOI $\left(4.1 \mathrm{~mL}, 2.9 \times 10^{-2} \mathrm{~mol}\right)$ under nitrogen. The reaction mixture was heated $35^{\circ} \mathrm{C}$, stirred for $40 \mathrm{~h}$ under nitrogen and then cooled to r.t. After evaporation of the solvent under reduced pressure, the residue was purified by column chromatography on silica gel with $n$-hexane/ethyl acetate $=2 / 1$ as eluent to af- ford MBiMOC. Further purification by recrystallization from $n$-hexane-ethyl acetate gave pure MBiMOC as colorless crystals: yield $74 \%$; $[\alpha]_{435}^{25}-87.8^{\circ}\left(c=1.0 \mathrm{~g} \mathrm{dL}^{-1}, l\right.$ $=10 \mathrm{~cm}, \mathrm{THF}) ;{ }^{1} \mathrm{H}$ NMR $\left(\delta\right.$, ppm from TMS in $\left.\mathrm{CDCl}_{3}\right)$ $8.00-7.12(\mathrm{~m}, 12 \mathrm{H}$, in binaphthalene group), $6.01(\mathrm{~s}$, $1 \mathrm{H}$, (trans) $\left.\mathrm{CH}_{2}=\mathrm{C}\right), 5.57\left(\mathrm{~s}, 1 \mathrm{H},(\right.$ cis $\left.) \mathrm{CH}_{2}=\mathrm{C}\right), 4.76(\mathrm{bs}$, $1 \mathrm{H}, \mathrm{N}-\mathrm{H}), 4.01-3.85\left(\mathrm{~m}, 2 \mathrm{H}, \mathrm{O}-\mathrm{CH}_{2}\right), 3.75\left(\mathrm{~s}, 3 \mathrm{H}, \mathrm{O}^{-}\right.$ $\left.\mathrm{CH}_{3}\right), 3.31-3.25\left(\mathrm{~m}, 2 \mathrm{H}, \mathrm{CH}_{2}-\mathrm{N}\right), 1.89\left(\mathrm{~s}, 3 \mathrm{H},\left(\mathrm{C}-\mathrm{CH}_{3}\right)\right.$; ${ }^{13} \mathrm{C}-\mathrm{NMR}\left(\delta\right.$, ppm from TMS in $\left.\mathrm{CDCl}_{3}\right) 166.95(\mathrm{C}=\mathrm{O})$, $154.82(\mathrm{~N}-\mathrm{C}=\mathrm{O}), 154.14,146.70,133.64,133.50,131.54$, $129.85,128.91,128.81,128.03,127.73,126.69,126.51$, $126.29,126.16,125.27,124.85,123.61,122.17,117.7$, 113.46 (in binaphthalene group), $135.78(=\mathrm{C}<$ ), 125.97 $\left(\mathrm{CH}_{2}=\right), 63.24\left(\mathrm{O}^{-} \mathrm{CH}_{2}\right), 56.53\left(\mathrm{O}^{-} \mathrm{CH}_{3}\right), 39.82\left(\mathrm{~N}-\mathrm{CH}_{2}\right)$, $18.22\left(\mathrm{CH}_{3}\right)$.

(S) - 2-Methoxy - 1, 1' - binaphthyl-2'- ( iso - propyloyloxyethyl)carbamate (MBiIOC). To a solution of MBiMOC $\left(0.3 \mathrm{~g}, 6.6 \times 10^{-4} \mathrm{~mol}\right)$ in dry dichloromethane $(10 \mathrm{~mL})$ was added palladium-activated carbon $(\mathrm{Pd} / \mathrm{C}, 0.3 \mathrm{~g})$. The reaction mixture was stirred for $48 \mathrm{~h}$ under hydrogen at r.t. and filtered. After evaporation of the solvent under reduced pressure, the residue was purified by column chromatography on silica gel with $n$-hexane/ethyl acetate $=1 / 2$ as eluent to obtain MBiIOC. Further purification by recrystallization from $n$-hexane-ethyl acetate gave pure MBiIOC as colorless crystals: yield $52 \%$; $[\alpha]_{435}^{25}$ $-61.3^{\circ}\left(c=1.0 \mathrm{~g} \mathrm{dL}^{-1}, l=10 \mathrm{~cm}, \mathrm{THF}\right) ;{ }^{1} \mathrm{H} \mathrm{NMR}(\delta$, ppm from TMS in $\left.\mathrm{CDCl}_{3}\right) 7.98-7.15(\mathrm{~m}, 12 \mathrm{H}$, in binaphthalene group), $4.76(\mathrm{bs}, 1 \mathrm{H}, \mathrm{N}-\mathrm{H}), 3.95-3.79(\mathrm{~m}, 2 \mathrm{H}, \mathrm{O}$ $\left.-\mathrm{CH}_{2}\right), 3.74\left(\mathrm{~s}, 3 \mathrm{H}, \mathrm{O}-\mathrm{CH}_{3}\right), 3.34-3.20\left(\mathrm{~m}, 2 \mathrm{H}, \mathrm{CH}_{2}-\mathrm{N}\right)$, $2.56-2.39(\mathrm{~m}, 1 \mathrm{H}, \mathrm{C}-\mathrm{H}), 1.89(\mathrm{~d}, 6 \mathrm{H}, J=4.29, \mathrm{C}-$ $\left.\left(\mathrm{CH}_{3}\right)_{2}\right)$.

\section{Radical Polymerization}

Radical homopolymerizations and copolymerizations were performed with AIBN as an initiator in suitable solvents under nitrogen in a sealed tube at $60^{\circ} \mathrm{C}$. After polymerization the polymer solution was poured into a 
large amount of methanol to precipitate the polymer. The resulting polymer was purified by reprecipitating it twice from the THF solution to excess methanol. The polymer was separated by decantation and dried in vacuo for 3 days. The composition of copolymer was calculated by elemental analysis $(\mathrm{N})$.

\section{Preparation of Packing Materials and Column Packing}

Synthetic routs of CSPs are shown in Scheme 2. Macroporous silica gel (MERCK, LiChrospher Si 1000: mean particle size, $10 \mu \mathrm{m}$; pore size $1000 \AA$ ), was silanized with dichlorodiphenylsilane according to the literature method. ${ }^{15}$ Poly(MBiMOC) $(0.2 \mathrm{~g})$ was dissolved in $10 \mathrm{~mL}$ of THF. Then, the silanized silica gel $(0.8 \mathrm{~g})$ was wetted with the polymer solution. After irradiation of the mixture with ultrasound for $20 \mathrm{~min}$, the solution was evaporated under reduced pressure to afford poly(MBiMOC)-coated-silica gel (CSP-I).

Macroporous silica gel (TOSOH, TSK-GEL Si 100: mean particle size, $5 \mu \mathrm{m}$; pore size $100 \AA$ ), was silanized

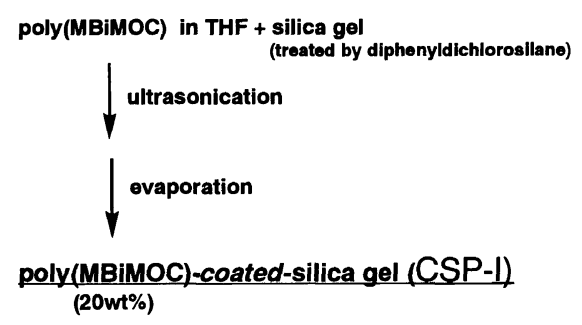

(2)

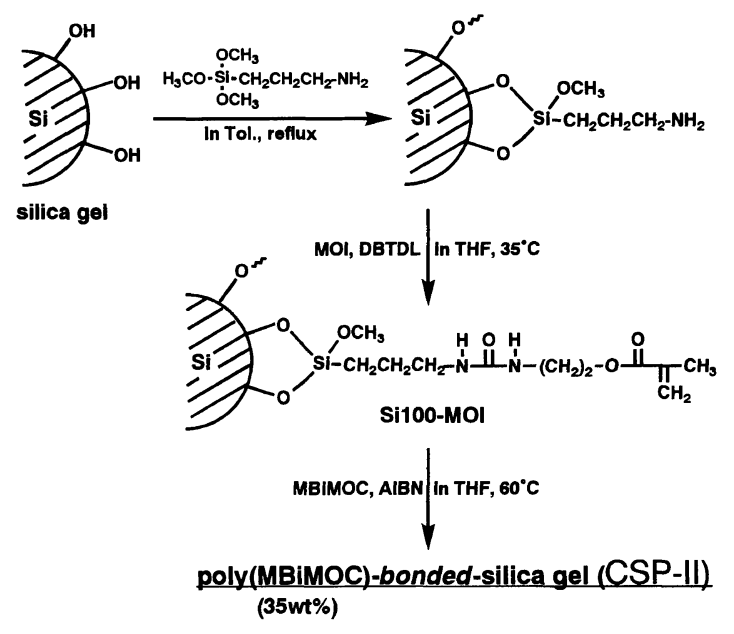

(3)
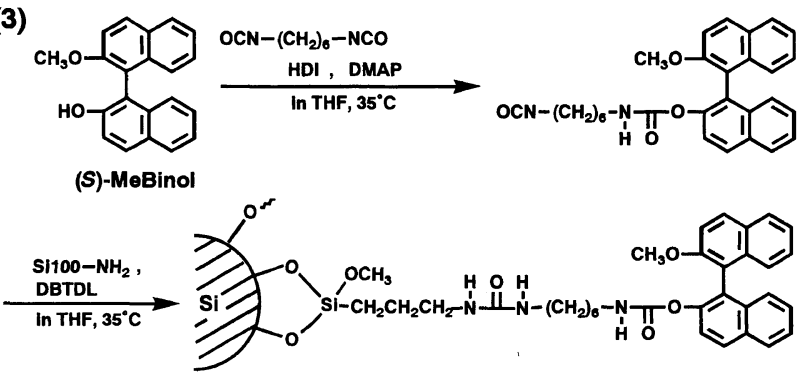

(S)-MeBinol-bonded-silica gel (CSP-III) (18wt\%)

Scheme 2. with 3-aminopropyl triethoxysilane to gave silica gel containing amino groups ( $\left.\mathrm{Si} 100-\mathrm{NH}_{2}\right)$ according to the literature method. ${ }^{16}$ MOI $\left(16 \mathrm{~mL}, 1.1 \times 10^{-1} \mathrm{~mol}\right)$ and di$n$-butyltin dilaurate (DBTDL, $0.01 \mathrm{~g}, 1.6 \times 10^{-5} \mathrm{~mol}$ ) were added to a slurry of Si $100-\mathrm{NH}_{2}(8.0 \mathrm{~g})$ in THF (80 $\mathrm{mL}$ ) under nitrogen. The mixture was heated at $35^{\circ} \mathrm{C}$, stirred for $45 \mathrm{~h}$ under nitrogen and then cooled to r.t. The reaction mixture was filtered, washed with THF, acetone, and methanol, and then dried in vacuo to obtain silica gel containing vinyl groups in the surface ( $\mathrm{Si}$ 100-MOI). Si 100-MOI (1.0 g) and MBiMOC (0.5 g) were placed in a Shlenk's reaction tube. A solution of AIBN (3 mol\% against MBiMOC) in THF ( $2 \mathrm{~mL}$ ) was added to the mixture in a Shlenk's reaction tube under nitrogen. The slurry was shaken at $60^{\circ} \mathrm{C}$ for $48 \mathrm{~h}$ and cooled to r.t. The reaction mixture was filtered, washed with THF, acetone and methanol, and then dried in vacuo to afford poly(MBiMOC)-bonded-silica gel (CSP-II). The content (35 wt\%) of MBiMOC segments on CSP-II was examined by IR.

To a mixture solution of $(S)$-MeBinol $\left(0.3 \mathrm{~g}, 9.6 \times 10^{-4}\right.$ mol) and DMAP $\left(0.01 \mathrm{~g}, 8.2 \times 10^{-5} \mathrm{~mol}\right)$ in THF $(10 \mathrm{~mL})$ was added hexamethylene diisocyanate (HDI, $0.16 \mathrm{~mL}$, $9.6 \times 10^{-4} \mathrm{~mol}$ ) under nitrogen. The mixture was heated at $35^{\circ} \mathrm{C}$ and stirred for $24 \mathrm{~h}$ under nitrogen. And Si 100 $\mathrm{NH}_{2}(1.0 \mathrm{~g})$ and DBTDL $\left(0.01 \mathrm{~g}, 1.6 \times 10^{-5} \mathrm{~mol}\right)$ were added to the reaction mixture. The mixture was further stirred for $72 \mathrm{~h}$ at $35^{\circ} \mathrm{C}$ under nitrogen, and then cooled to r.t. The reaction mixture was filtered, washed with THF, acetone, and methanol, and then dried in vacuo to obtain (S)-MeBinol-bonded-silica gel (CSP-III). The content $(18 \mathrm{wt} \%)$ of $(S)-\mathrm{MeBinol}$ segments on CSP-III was examined by IR.

The CSPs was packed in a stainless steel for HPLC column (internal diameter, $0.2 \mathrm{~mm}$; length, $15 \mathrm{~cm}$ ) by a slurry method. Theoretical plate numbers of the columns packed CSP-I, CSP-II, and CSP-III were 370, 340, and 1040, respectively, which were measured for toluene in methanol as eluent at a flow rate of $0.5 \mathrm{~mL} \mathrm{~min}^{-1}$ at ambient temperature.

\section{Measurements}

NMR spectra were recorded at $25^{\circ} \mathrm{C}$ using JEOL EX270 (JEOL Ltd.). Infrared spectra were recorded using Shimadzu FT IR-8100A (Shimadzu Ltd.). Gel permeation chromatography (GPC) measurements were carried out at $50^{\circ} \mathrm{C}$ using THF as eluent on a Shimadzu SPD-10 A (Shimadzu Ltd.) equipped with a UV detector (254 nm), HSG-40, HSG-20, HSG-15, and HSG-10 columns, and a polarimetric detector Jasco OR 990 (Japan Spectroscopic Co.). Specific optical rotations were measured with a Jasco DIP-140 (5 and $10 \mathrm{~cm}$ quartz cell lengths, $c$ $=1.0 \mathrm{~g} \mathrm{dL}^{-1}$ in THF). Circular dichroism (CD) spectra were obtained at $25^{\circ} \mathrm{C}$ by a Jasco J-20 C equipped with a xenon source and a computing data processor $(0.1 \mathrm{~mm}$ quartz cell length $c=0.1 \mathrm{~g} \mathrm{dL}^{-1}$ in THF). HPLC measurements were carried out on a Shimadzu LC-10 AT with UV detection at $254 \mathrm{~nm}$. Elemental analysis was carried out with a CHN recorder (Yanagimoto Co.). 


\section{RESULTS AND DISCUSSION}

\section{Radical Homopolymerizations of MBiMOC}

Radical polymerizations of MBiMOC were performed with $\mathrm{AIBN}$ as an initiator at $60^{\circ} \mathrm{C}$ in various solvents. The results are summarized in Table I. All polymerizations except in benzene proceeded homogeneously throughout, in the solvent a slight precipitate was observed. The obtained polymers were white powders and soluble in organic solvents such as acetone, chloroform, and THF. Figure 1 shows ${ }^{1} \mathrm{H}$ NMR spectra of MBiMOC and poly(MBiMOC). The peaks at $6.01 \mathrm{ppm}$ and 5.57 ppm assigned to vinyl $\left(\mathrm{CH}_{2}=\mathrm{C}<\right)$ groups disappeared, and the peak at $4.76 \mathrm{ppm}$ due to carbamate (-NHCOO-) groups became broad and shifted to $5.36 \mathrm{ppm}$ after polymerization, indicating that the radical polymerization completely proceeded. Expanded IR spectra of MBiMOC and poly(MBiMOC) measured in chloroform are shown

Table I. Radical polymerization of MBiMOC at $60^{\circ} \mathrm{C}$ for $24 \mathrm{~h}^{\mathrm{a}}$

\begin{tabular}{|c|c|c|c|c|c|}
\hline \multirow{2}{*}{ Run } & \multirow{2}{*}{$\begin{array}{l}\text { Polym. } \\
\text { sol. }\end{array}$} & Yield $^{\mathrm{b}}$ & $\bar{M}_{\mathrm{n}}^{\mathrm{c}}$ & \multirow{2}{*}{$\bar{M}_{\mathrm{w}} / \bar{M}_{\mathrm{n}}{ }^{\mathrm{c}}$} & {$[\alpha]_{435}^{25 d}$} \\
\hline & & $\%$ & $\times 10^{-4}$ & & deg. \\
\hline 1 & Benzene & 96.4 & 3.40 & 15.3 & -80.3 \\
\hline 2 & $\mathrm{CHCl}_{3}$ & 89.4 & 4.15 & 12.9 & -80.6 \\
\hline 3 & THF & 86.4 & 1.35 & 5.30 & -82.9 \\
\hline 4 & DMF & 86.1 & 1.90 & 6.21 & -79.1 \\
\hline
\end{tabular}

${ }^{\mathrm{a}}$ Monomer: $0.55 \mathrm{~mol} \mathrm{~L}^{-1}$; polym. sol.: $2 \mathrm{~mL}$; initiator: $2.2^{\prime}$ azobisisobutyronitrile, $3 \mathrm{~mol} \%$. ${ }^{\mathrm{b}} \mathrm{MeOH}$-insoluble part. ${ }^{\mathrm{c}} \mathrm{By}$ GPC with standard polystyrene. ${ }^{\mathrm{d}} c=1.0 \mathrm{~g} \mathrm{dL}^{-1}, l=10 \mathrm{~cm}$, THF.
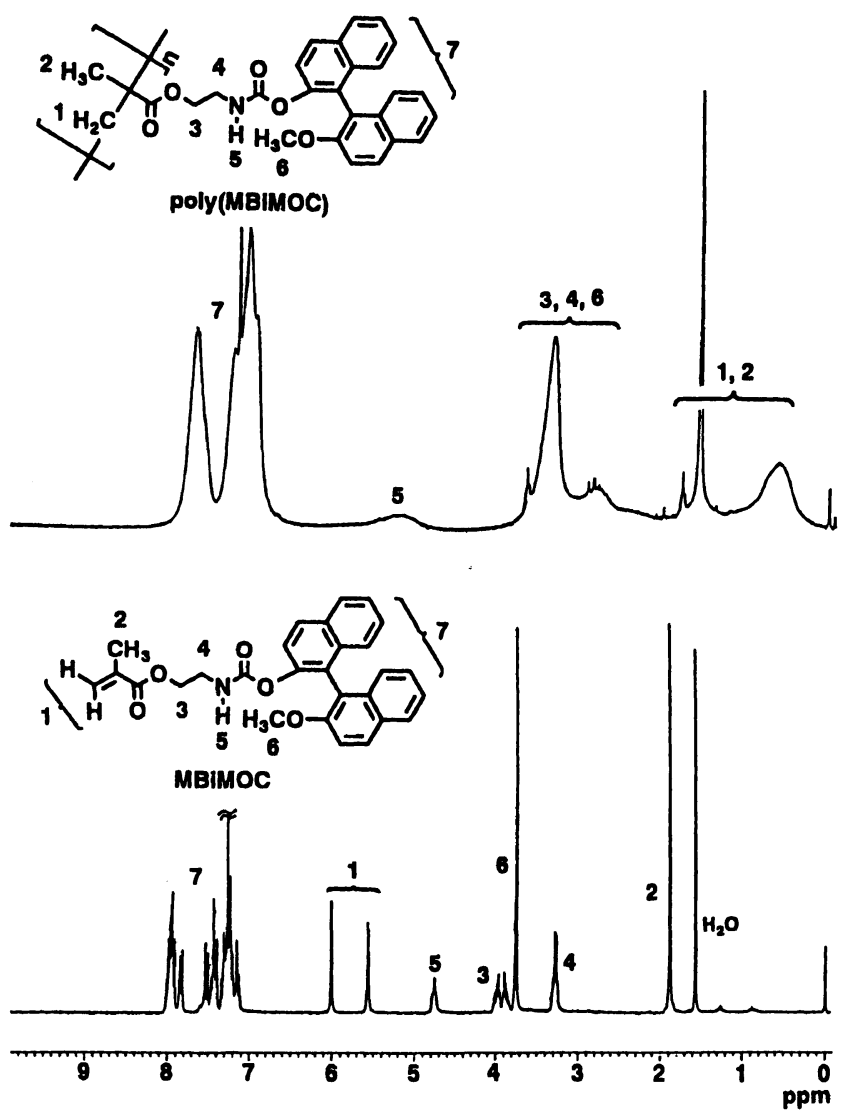

Figure 1. ${ }^{1} \mathrm{H}$ NMR spectra for MBiMOC and poly(MBiMOC) in $\mathrm{CDCl}_{3}$ at $23.5^{\circ} \mathrm{C}(270 \mathrm{MHz})$. in Figure 2. A sharp absorption peak due to stretching vibration of $\mathrm{N}-\mathrm{H}$ for MBiMOC appeared at around 3450 $\mathrm{cm}^{-1}$. For poly(MBiMOC), the peak shifted from around $3450 \mathrm{~cm}^{-1}$ to around $3380 \mathrm{~cm}^{-1}$ and became broad, suggesting that the poly(MBiMOC) had hydrogen bonds based on urethane segments. Figure 3 shows ${ }^{1} \mathrm{H}$ NMR spectra of poly(MBiMOC) measured at various temperatures. With increasing temperature, the broad peak due to carbamate groups at $5.36 \mathrm{ppm}$ shifted slightly to high magnetic field. Thus the poly(MBiMOC) may have intrarather than intermolecular hydrogen bonds.

GPC curves of poly(MBiMOC) are shown in Figure 4. The top curves taken with a polarimetric detector displayed a negative peak whose pattern was quite similar to the bottom curves of the corresponding UV curve. Thus chiroptical property of poly(MBiMOC) may not be affected by molecular weight. GPC curves for poly(MBiMOC) obtained in benzene exhibited binary peaks (Figure $4(1)$ ), which may be associated with a slight precipitate observed during polymerization. Poly(MBiMOC) obtained in various solvents showed specific optical rotations $\left([\alpha]_{435}^{25}\right)$ of $-79.1--82.9^{\circ}$ (Table I), indicating that the chiroptical property of the polymer may not almost
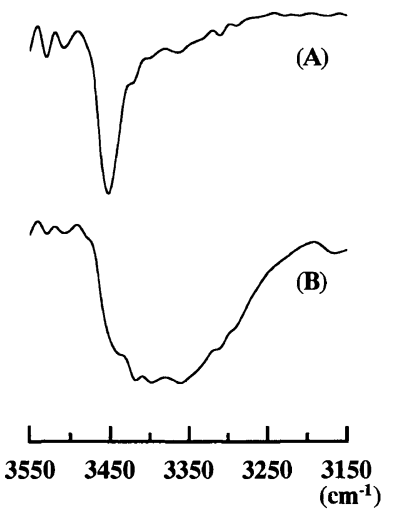

Figure 2. IR spectra for (A) MBiMOC and (B) poly(MBiMOC) in chloroform; $c=2.0 \mathrm{~g} \mathrm{dL}^{-1}$.

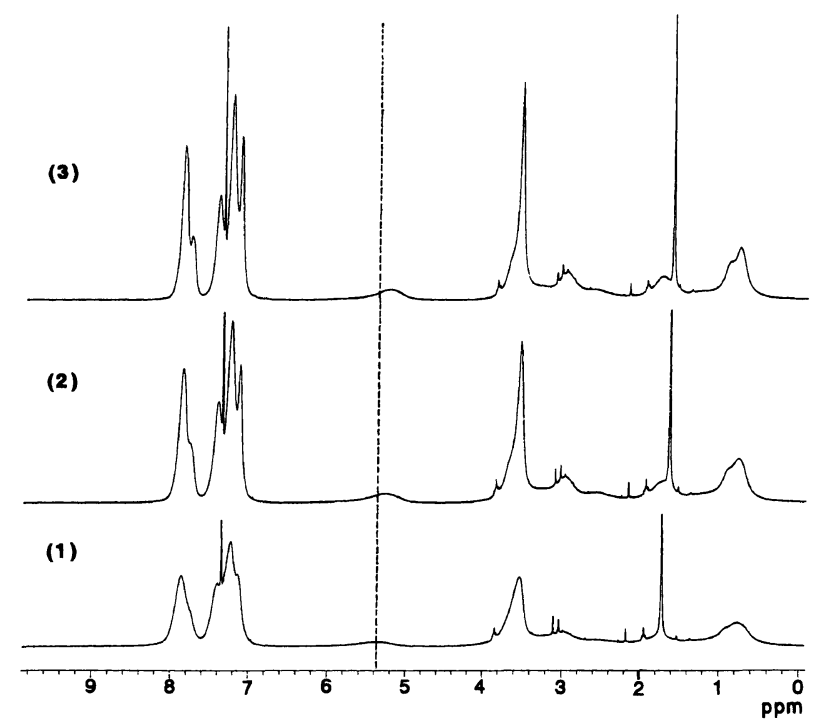

Figure 3. ${ }^{1} \mathrm{H}$ NMR spectra for poly(MBiMOC) in $\mathrm{CDCl}_{3}$ at (1) $23.5^{\circ} \mathrm{C}$, (2) $40^{\circ} \mathrm{C}$, and $(3) 50^{\circ} \mathrm{C}$.

Polym. J., Vol. 33, No. 5, 2001 


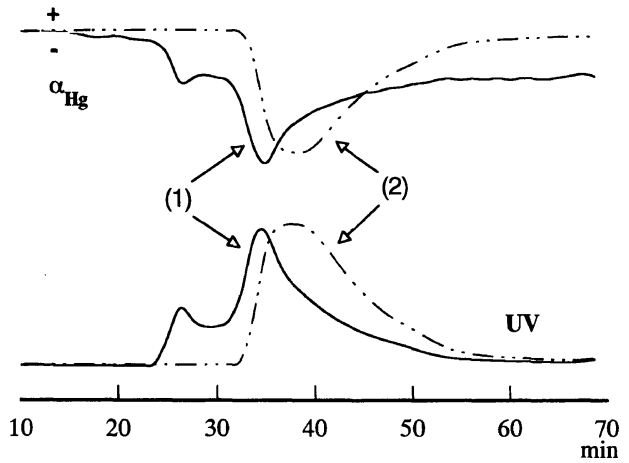

Figure 4. GPC curves for poly(MBiMOC); polymerization solvents: (1) benzene (run 1 in Table I) and (2) THF (run 3 in Table I).

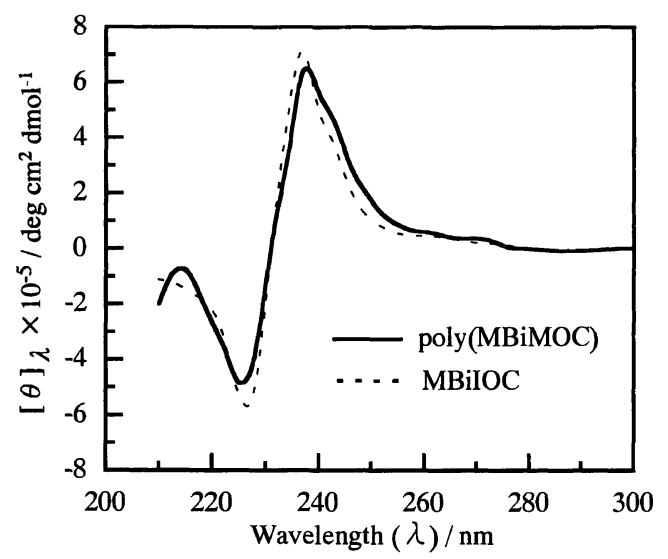

Figure 5. CD spectra of poly(MBiMOC) (run 3 in Table I) and MBiIOC.

be affected by the polymerization solvents. The specific optical rotations of the poly(MBiMOC) were different from that of MBiIOC as model compound $\left(-61.3^{\circ}\right)$ but the CD pattern of poly(MBiMOC) was comparable to that of MBiIOC, as shown in Figure 5. In the Figure, positive Cotton effect at around $235 \mathrm{~nm}$ and negative one at around $225 \mathrm{~nm}$ due to ${ }^{1} \mathrm{~B}_{\mathrm{b}}$ transition for $1,1^{\prime}$ binaphthalene group were observed.

The results of the specific optical rotations of poly(MBiMOC) measured in benzene and THF at various temperatures are shown in Figure 6. Absolute values of the specific optical rotations increased with increasing temperature $(|\Delta[\alpha] / \Delta T|=0.41$ and 0.80 in benzene and $\mathrm{THF}$, respectively), and the changes were reversible. These changes may be attributed to change of conformation caused by hydrogen bonds due to urethane segments. Previously, we reported ${ }^{13}$ that temperature dependence of specific optical rotation of poly(ChMOC) might be in part due to conformation changed by both strong hydrogen bonds based on the urethane groups and interaction between cholesteryl groups. Absolute values of the specific optical rotations of poly(MBiMOC) in benzene/trifluoroacetic acid (TFA) (9.8/0.2 volume $)$ decreased slightly with increasing temperature $(\mid \Delta[\alpha] /$ $\Delta T \mid=0.12$ ) because TFA acted as an inhibitor for the formation of hydrogen bonds. Thus, not only hydrogen bonds due to urethane segments but also $\pi-\pi$ interaction between 1,1'-binaphthyl groups may affect the conformation of poly(MBiMOC) (Scheme 3).

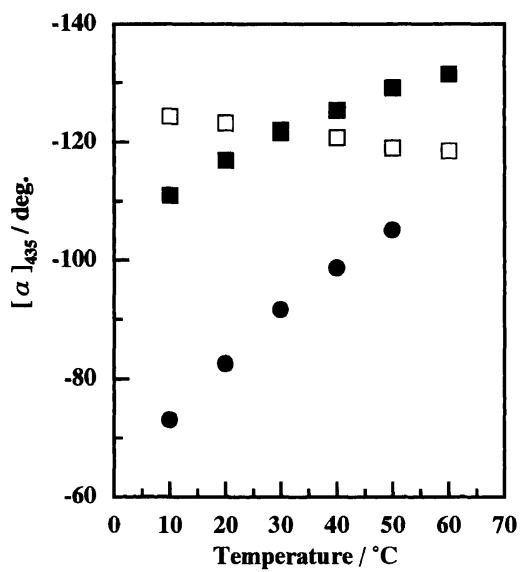

Figure 6. Dependence of specific optical rotation of poly( $\mathrm{MBi}$ MOC) on the measurement temperature in ( THF, ( $\square$ ) benzene, and $(\square)$ benzene/trifluoroacetic acid $\left(9.8 / 0.2_{\text {volume }}\right) ; c=1.0 \mathrm{~g} \mathrm{dL}^{-1} ; l$ $=10 \mathrm{~cm}$.

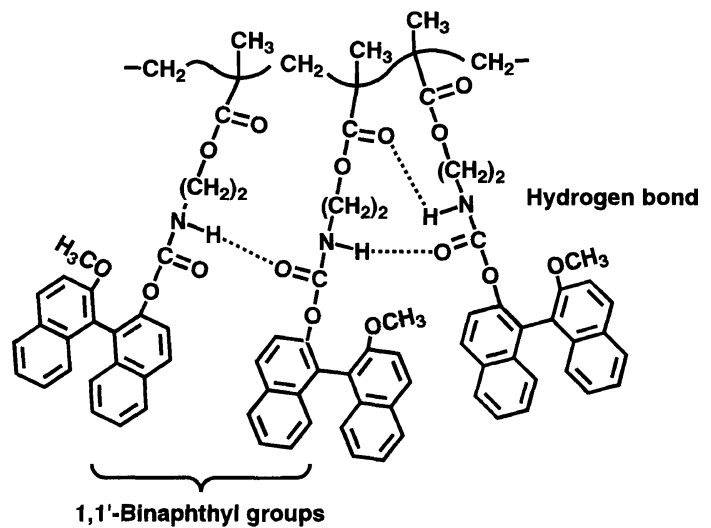

Scheme 3.

\section{Copolymerizations of MBiMOC with ST or MMA}

The results of radical copolymerizations of MBiMOC $\left(\mathrm{M}_{1}\right)$ with ST $\left(\mathrm{M}_{2}\right)$ or MMA $\left(\mathrm{M}_{2}\right)$ using AIBN in toluene at $60^{\circ} \mathrm{C}$ are summarized in Table II. All copolymerizations proceeded homogeneously. The copolymers were white powders, and optically active. Figure 7 shows copolymer composition curves in the copolymerizations of MBiMOC with ST or MMA. Monomer reactivity ratios $\left(r_{1}, r_{2}\right)$ determined according to the high-conversion method reported by Tüdös et al. ${ }^{17}$ and Alfrey-Price ${ }^{18} Q-e$ values are as follows: $r_{1}=0.01, r_{2}=0.18, Q_{1}=0.68, e_{1}=$ 1.83 for MBiMOC-ST system; $r_{1}=0.70, r_{2}=0.64, Q_{1}=$ $1.64, e_{1}=1.29$ for MBiMOC-MMA system. $Q_{1}$ and $e_{1}$ values in the MBiMOC-ST system were different from those in the MBiMOC-MMA system. In the Alfrey-Price $Q$ and $e$ theory, no steric effect is taken into account. MBiMOC seems to have relatively high steric hindrance because of the large 1,1'-binaphthalene group. These copolymerization parameters are similar to those for other substituted-( $N$-methacryloyloxyethyl)carbamate(RMOC) copolymers. ${ }^{6,13}$

Figure 8 shows relationships between specific optical rotations and the content (wt\%) of monomeric unit of MBiMOC in poly(MBiMOC-co-M $\mathrm{M}_{2}$ )s. Absolute values of $[\alpha]_{435}^{25}$ of the copolymers increased with an increase in the content of MBiMOC monomeric units. A line con- 
Table II. Radical copolymerizations of MBiMOC $\left(\mathrm{M}_{1}\right)$ with ST $\left(\mathrm{M}_{2}\right)$ and MMA $\left(\mathrm{M}_{2}\right)$ in THF $(1 \mathrm{~mL})$ at $60^{\circ} \mathrm{C}^{\mathrm{a}}$

\begin{tabular}{|c|c|c|c|c|c|c|c|c|c|}
\hline \multirow[t]{2}{*}{ Run } & \multirow[t]{2}{*}{$\mathrm{M}_{2}$} & \multirow{2}{*}{$\begin{array}{c}\begin{array}{c}\mathrm{M}_{1} \text { in } \\
\text { monomer }\end{array} \\
\text { mol\% }\end{array}$} & \multirow{2}{*}{$\begin{array}{c}\begin{array}{c}\text { Polym. } \\
\text { time }\end{array} \\
\mathrm{h}\end{array}$} & \multirow{2}{*}{$\frac{\text { Yield }^{\mathrm{b}}}{\%}$} & \multicolumn{2}{|c|}{$\begin{array}{c}\mathrm{M}_{1} \text { in } \\
\text { copolymer }^{\mathrm{c}}\end{array}$} & \multirow{2}{*}{$\frac{\bar{M}_{\mathrm{n}}^{\mathrm{d}}}{\times 10^{-4}}$} & \multirow[t]{2}{*}{$\bar{M}_{\mathrm{w}} / \bar{M}_{\mathrm{n}}^{\mathrm{d}}$} & \multirow{2}{*}{$\frac{[\alpha]_{435}^{25 \mathrm{e}}}{\mathrm{deg} .}$} \\
\hline & & & & & $\mathrm{mol} \%$ & wt $\%$ & & & \\
\hline 1 & $\mathrm{ST}$ & 10.0 & 3.0 & 6.0 & 30.6 & 65.8 & 1.77 & 2.07 & -32.4 \\
\hline 2 & $\mathrm{ST}$ & 29.5 & 2.5 & 5.2 & 41.7 & 75.8 & 1.85 & 2.33 & -53.4 \\
\hline 3 & $\mathrm{ST}$ & 49.3 & 2.5 & 6.5 & 38.1 & 72.9 & 1.92 & 2.61 & -60.9 \\
\hline 4 & $\mathrm{ST}$ & 68.8 & 2.0 & 4.3 & 55.1 & 84.3 & 2.22 & 3.14 & -58.6 \\
\hline 5 & $\mathrm{ST}$ & 86.5 & 2.0 & 8.6 & 51.4 & 82.2 & 3.15 & 3.86 & -69.6 \\
\hline 6 & MMA & 9.9 & 1.0 & 14.4 & 11.5 & 37.3 & 5.47 & 5.09 & -35.9 \\
\hline 7 & MMA & 29.7 & 0.5 & 16.8 & 23.8 & 58.6 & 6.07 & 8.07 & -65.4 \\
\hline 8 & MMA & 47.9 & 0.5 & 23.4 & 63.9 & 88.5 & 7.80 & 10.5 & -73.0 \\
\hline 9 & MMA & 69.7 & 0.5 & 33.1 & 72.5 & 92.3 & 11.6 & 13.8 & -78.8 \\
\hline 10 & MMA & 85.2 & 0.5 & 42.6 & 80.9 & 95.1 & 12.7 & 15.0 & -80.0 \\
\hline
\end{tabular}

${ }^{\mathrm{a}} \mathrm{M}_{1}+\mathrm{M}_{2}=0.5 \mathrm{~g}$, initiator: 2,2'-azobisisobutyronitrile $\left(0.03 \mathrm{~mol} \mathrm{~L}{ }^{-1}\right) .{ }^{\mathrm{b}} \mathrm{MeOH}$-insoluble part. ${ }^{\mathrm{c}}$ By elemental anlysis $(\mathrm{N}) .{ }^{\mathrm{d}} \mathrm{By}$ GPC with polystyrene standard. ${ }^{\mathrm{e}} l=10,5 \mathrm{~cm}$, THF, $c=1.0-0.3 \mathrm{~g} \mathrm{dL}^{-1}$.

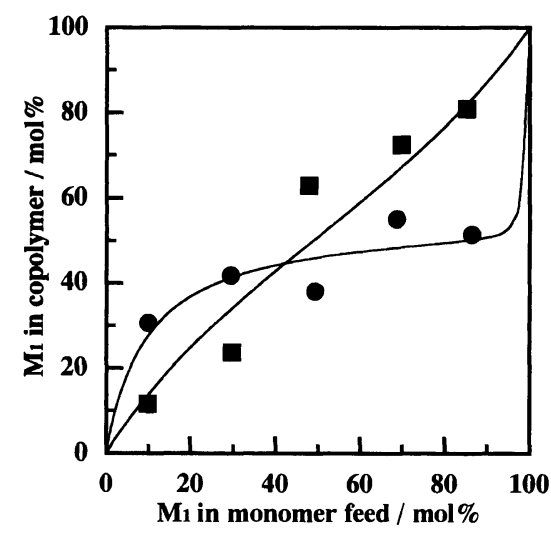

Figure 7. Copolymerization composition curves for poly$\left(\mathrm{MBiMOC}-\mathrm{co}-\mathrm{M}_{2}\right) ; \mathrm{M}_{2}=(\bigcirc) \mathrm{ST}$ and (ロ) MMA.

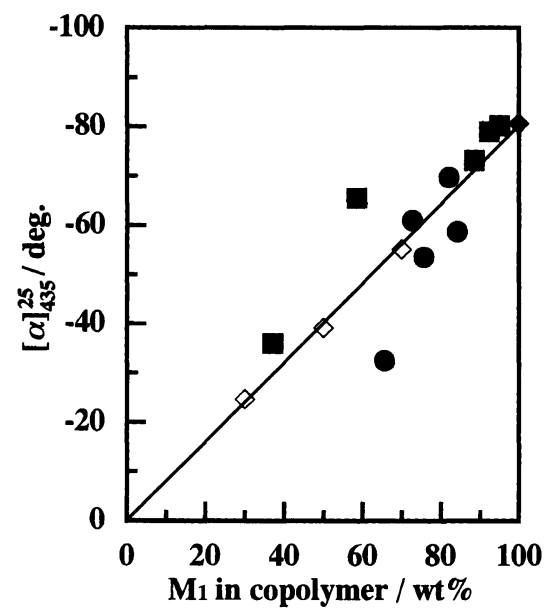

Figure 8. Relationships between specific optical rotations and contents (wt\%) of the monomeric unit of MBiMOC in poly(MBiMOC-co- $\mathrm{M}_{2}$ ); $\mathrm{M}_{2}=(\bigcirc) \mathrm{ST}$ and ( $\square$ ) MMA; ( $)$ poly(MBiMOC); $(\diamond)$ mixtures of poly(MBiMOC) and poly $(\mathrm{ST})$.
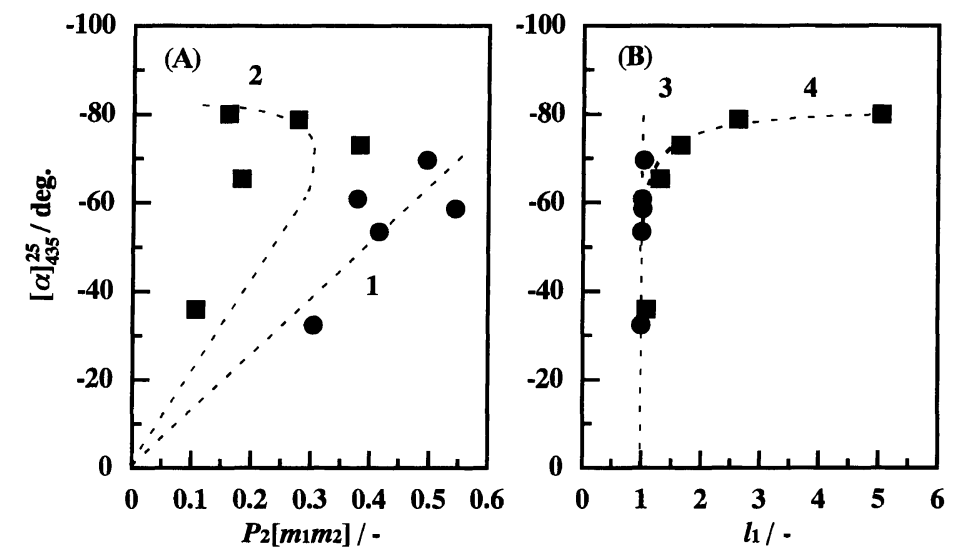

Figure 9. Relationships between specific optical rotations and (A) diad sequence $\left(P_{2}\left[m_{1} m_{2}\right]\right)$ and (B) average sequence length $\left(l_{1}\right)$ in poly$\left(\mathrm{MBiMOC}-\mathrm{co}-\mathrm{M}_{2}\right) ; \mathrm{M}_{2}=(\mathrm{O}) \mathrm{ST}$ and (ロ) MMA.

necting $0^{\circ}$ with $[\alpha]_{435}^{25}$ of poly(MBiMOC) refers to the relationship between the specific optical rotations and contents $(\mathrm{wt} \%)$ of the monomeric unit of a mixture of poly(MBiMOC) and poly(ST) [or poly(MMA)]. In Figure 8, the specific optical rotations of poly $\left(\mathrm{MBiMOC}-\mathrm{co}-\mathrm{M}_{2}\right) \mathrm{s}$ show a deviation from the line, indicating that the chiroptical properties of the copolymers depend markedly on co-units.
Figure 9 shows dependence of specific optical rotations of the copolymers on a diad sequence $\left(P_{2}\left[m_{1} m_{2}\right]\right)^{19,20}$ and average sequence length of MBiMOC units $\left(l_{1}\right)^{21}$. $P_{2}\left[m_{1} m_{2}\right]$ indicates probability of a $\mathbf{M}_{1}-\mathrm{M}_{2}$ diad sequence. $P_{2}\left[m_{1} m_{2}\right]$ was derived as follows:

$$
\begin{gathered}
P_{1}\left[m_{1}\right]+P_{1}\left[m_{2}\right]=1 \\
P_{2}\left[m_{1} m_{2}\right]=P_{1}\left[m_{1}\right] P\left(m_{1} m_{2}\right)
\end{gathered}
$$




$$
P\left(m_{1} m_{2}\right)=1 /\left(1+r_{1} X\right)
$$

where $P_{1}\left[m_{1}\right]$ and $P_{1}\left[m_{2}\right]$ are molar fractions of the copolymer, $P\left(m_{1} m_{2}\right)$ is given by the monomer molar ratio in the feed $\left(X=\mathrm{M}_{1} / \mathrm{M}_{2}\right)$, and $r_{1}$ in the monomer reactivity ratio of MBiMOC. Specific optical rotations of poly(MBiMOC-co-ST)s increased with increasing the diad sequence (broken line 1), indicating that chiroptical properties of the polymers may be strongly influenced by the MBiMOC-ST sequence. On the other hand, such a relationship was not observed for the MBiMOC-MMA system, suggesting that chiroptical properties of the copolymers may be influenced by both MBiMOC-MMA diad sequence and the average sequence length of $\mathrm{MBi}$ MOC units in poly(MBiMOC-co-MMA)s, as shown in Figure 9B, broken line 4.

\section{Chiral Recognition Ability of Poly(MBiMOC)}

To investigate chiral recognition ability of poly(MBiMOC), three types of CSPs, poly(MBiMOC)-coated-silica gel (CSP-I), poly(MBiMOC)-bonded-silica gel (CSP-II), and $(S)$-MeBinol-bonded-silica gel (CSP-III), were prepared according to synthetic routs of Scheme 2. Figure 10 depicts IR spectra of poly(MBiMOC), silica gel, and poly(MBiMOC)-bonded-silica gel. For poly(MBiMOC)bonded-silica gel, absorption due to $1,1^{\prime}$-binaphthalene groups appeared clearly at $750 \mathrm{~cm}^{-1}$. The content (wt\%) of poly(MBiMOC) segments on CSP-II was determined

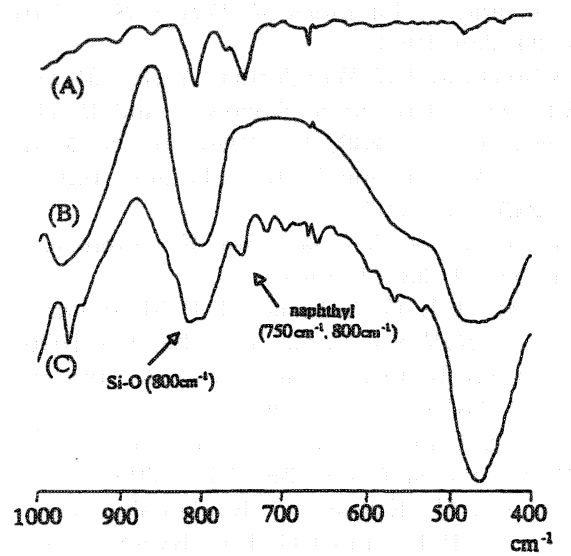

Figure 10. IR spectra of (A) poly(MBiMOC), (B) silica gel, and (C) poly(MBiMOC)-bonded-silica gel. by calibration curves obtained from the ratios $\left(\mathrm{A}_{750 \mathrm{~cm}^{-1}} /\right.$ $\left.A_{800 \mathrm{~cm}^{-1}}\right)$ of absorbance at $750 \mathrm{~cm}^{-1}$ and $800 \mathrm{~cm}^{-1}$ in IR spectra of suitable mixtures of silica gel and chiral polymers, as shown in Figure 11.

Poly(MBiMOC) has an urethane bond and a bulky $1,1^{\prime}$-binaphthalene moiety. Hence, hydrogen bond due to urethane bond and $\pi-\pi$ interaction due to $1,1^{\prime}$ binaphthalene moiety are expected between CSPs and racemates. Table III shows the results of the HPLC analysis of racemates compounds $1-7$ (Scheme 4) using 2-propanol $/ n$-hexane as mobile phase. Racemates 1, 2, and 4-7 were resolved on CSP-I, and racemates $1-\mathbf{3}$ were resolved on CSP-II. As an example, Figure 12 shows the typical chromatogram of the resolution of racemate 3 on the CSP-II column. CSP-III did not resolve all racemates $\mathbf{1 - 7}$. Difference in chiral resolution ability between CSP-I, CSP-II, and CSP-III indicates that chiral resolution ability of poly(MBiMOC) may be based not only on the urethane and $1,1^{\prime}$ binaphthalene moieties in MBiMOC units, but on higher-ordered structure of the polymer. Miyano et al. ${ }^{11}$ have been synthesized and polymerized chiral methacrylate bearing only 1,1'-binaphthalene group, i.e., 2-( 3 -methacryloyloxypropoxy ) $-2^{\prime}$-methoxy-1,1'binaphthalene, and examined chiral recognition ability of the polymer. However, the chiral recognition ability of the poly(methacrylate) was not due to the secondary and/or higher-ordered structure of the polymer, but the

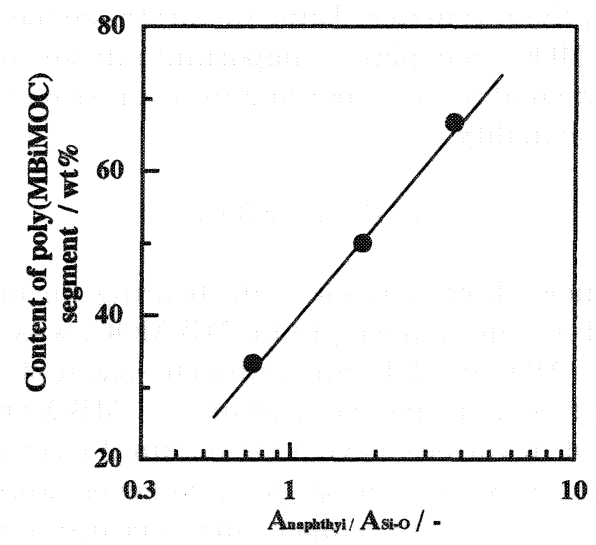

Figure 11. Calibration curve for content (wt\%) of MBiMOC segments in poly(MBiMOC)-bonded-silica gel.

Table III. Chromatographic resolution of racemates $1-7$ on the CSP-I and CSP-II ${ }^{\mathrm{a}}$

\begin{tabular}{|c|c|c|c|c|c|c|c|c|c|c|c|c|c|c|c|}
\hline \multirow[b]{2}{*}{ Racemates } & \multicolumn{5}{|c|}{ CSP-I } & \multicolumn{5}{|c|}{ CSP-II } & \multicolumn{5}{|c|}{ CSP-III } \\
\hline & $\frac{\text { flow }}{\mathrm{mL} \min ^{-1}}$ & $k_{1}^{\prime b}$ & $k_{2}^{\prime b}$ & $\alpha^{\mathrm{c}}$ & $R_{\mathrm{s}}^{\mathrm{d}}$ & $\frac{\text { flow }}{\mathrm{mL} \mathrm{min}^{-1}}$ & $k_{1}^{\prime}$ & $k_{2}^{\prime}$ & $\alpha$ & $R_{\mathrm{s}}$ & $\frac{\text { flow }}{\mathrm{mL} \mathrm{min}^{-1}}$ & $k_{1}^{\prime}$ & $k_{2}^{\prime}$ & $\alpha$ & $R_{\mathrm{g}}$ \\
\hline 1 & $0.05^{\mathrm{e}}$ & 0.26 & 0.38 & 1.45 & 0.52 & $0.05^{\mathrm{e}}$ & 0.94 & 1.06 & 1.16 & 0.53 & $0.10^{\mathrm{e}}$ & 1.91 & & & \\
\hline 2 & 0.05 & 0.51 & 0.74 & 1.42 & 0.48 & $0.10^{f}$ & 1.96 & 2.65 & 1.35 & 0.73 & 0.10 & 1.18 & & & \\
\hline 3 & 0.20 & 1.10 & & & & 0.50 & 6.47 & 12.5 & 1.94 & 1.41 & 0.50 & 0.99 & & & \\
\hline 4 & 0.10 & 0.21 & 0.45 & 2.14 & 0.75 & 0.10 & 1.85 & & & & 0.10 & 0.46 & & & \\
\hline 5 & 0.10 & 0.44 & 0.59 & 1.34 & 0.26 & 0.10 & 0.95 & & & & 0.10 & 5.63 & & & \\
\hline 6 & 0.05 & 0.24 & 0.43 & 1.79 & 0.27 & 0.10 & 1.15 & & & & 0.10 & 0.27 & & & \\
\hline 7 & 0.05 & 0.30 & 0.43 & 1.43 & 0.22 & 0.10 & 1.33 & & & & 0.10 & 0.43 & & & \\
\hline
\end{tabular}

${ }^{a}$ CSP-I, poly(MBiMOC)-coated-silica gel; CSP-II, poly(MBiMOC)-bonded-silica gel; CSP-III, (S)-MeBinol-bonded-silica gel; mobile phase, $n$-hexane $/ 2$-propanol $=9.5 / 0.5_{\text {volume }} \quad{ }^{\mathrm{b}}$ Capacity factor of the enantiomer eluting first $\left(k_{1}{ }^{\prime}\right)$ and second $\left(k_{2}{ }^{\prime}\right)=($ retention time of enantiomervoid time of column)/(retention time of triphenylmethane). ${ }^{c}$ Separation factor $=k_{2}^{\prime} / k_{1}{ }^{\prime}$. ${ }^{d}$ Resolution factor $=2 \times($ distance between the peaks of more and ress retained enantiomers)/(sum of bandwidth of two peaks). " Mobile phase, $n$-hexane $/ 2$-propanol $=9.0 / 1.0_{\text {volume }}$.

${ }^{\mathrm{f}}$ Mobile phase, $n$-hexane $/ 2$-propanol $=8.0 / 2.0_{\text {volume }}$. 

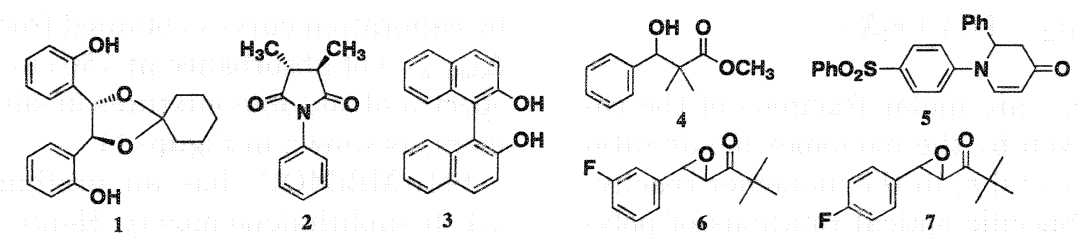

Scheme 4.

1: trans-2-Cyclohexanespiro-4,5-di (o-hydroxyphenyl)-1,3-dioxolane 3: 2,2'-Bi-1-naphthol

5: 2-Phenyl- $N$-( $p$-(phenylsulfonyl)phenyl)-4-pyridone

7: trans-Epoxy-1-(4-fluorophenyl)-4,4-dimethylpentane-3-one
2: trans-3,4-Dimethyl- $N$-phenylsuccinimide 4: Methoxycarbonyl-2,2-dimethyl-1-phenylethanol 6: trans-Epoxy-1-(3-fluorophenyl)-4,4-dimethylpentane-3-one

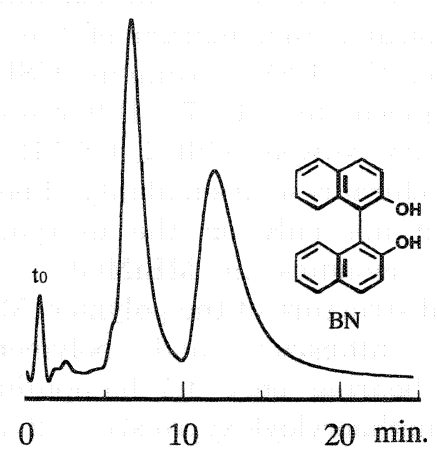

Figure 12. HPLC chromatogram of racemate 3 with CSP-II in $n$ hex./2-propanol (9/1) as mobile phases; column, $150 \mathrm{~mm} \times 2 \mathrm{~mm}$; flow $=0.5 \mathrm{~mL} \mathrm{~min}^{-1}$; detection, UV $(254 \mathrm{~nm})$.

interaction between the individual 1,1'-binaphthalene units and the racemates. Thus, the urethane moieties in poly(MBiMOC) may play an important role for control of conformation of the polymer and for expression of chiral recognition ability.

\section{CONCLUSION}

1. A new chiral methacrylate bearing an urethane and a 1,1'-binaphthalene group, MBiMOC, was synthesized from MOI and 1,1'-binaphthalene-2,2'-diol.

2. Radical homopolymerizations of MBiMOC were carried out in various solvents to obtain the corresponding polymers whose chiroptical properties were influenced by solvents and temperatures because poly( $\mathrm{MBi}-$ MOC) had hydrogen bond caused by urethane units in solvent.

3. From the results of the copolymerizations of MBiMOC with ST or MMA, monomer reactivity ratios, $Q$, and $e$ values were determined. Chiroptical properties of the copolymers were influenced by co-units.

4. CSPs prepared silica gel and poly(MBiMOC) resolved racemates $\mathbf{1}-\mathbf{7}$ by HPLC. The chiral recognition ability of poly(MBiMOC) may be attributed to higherordered structure of the polymer.

Acknowledgment. The authors are thankful to Showa Denko Co. Ltd. for supplying the MOI.

\section{REFERENCES}

1. S. G. Allenmark, "Chromatographic Enantioseparation", Ellis Howood Ltd., Chichester, 1988.

2. For example, Y. Okamoto, CHEMTECH, 176 (1987).

3. Y. Tamai, P. Qian, K. Matsunaga, and S. Miyano, Bull. Chem. Soc. Jpn., 65, 817 (1992).

4. a) G. Blaschke, Angew. Chem., Int. Ed., Engl., 19, 13 (1980); b) G. Blaschke, W. Broker, and E. Frankel, Angew. Chem., Int. Ed., Engl., 25, 830 (1986).

5. D. Arlt, B. Bomer, R. Grosser, and W. Lange, Angew. Chem., Int. Ed., Engl., 30, 1662 (1991).

6. Y. K. Lee, K. Onimura, H. Tsutsumi, and T. Oishi, Polym. J., 32, 1021 (2000).

7. S. Matsuhiro, Konbatekku, 5, 8 (1997).

8. a) H. Kamogawa, H. Kohno, and R. Kitagawa, J. Polym. Sci., Part A: Polym. Chem., 27, 487 (1989); b) C. Decker and K. Moussa, Eur. Polym. J., 27, 881 (1991); c) I. Francis, S. Arjen, C. Israel, and S. Johannes, J. Polym. Sci., Part A: Polym. Chem., 31, 239 (1993).

9. a) H. Albrecht and W. Wunderlich, Angew. Makromol. Chem., 145/146, 89 (1986); b) S. Savaskan and B. Hazer, Angew. Makromol. Chem., 239, 13 (1996); (c) N. Monzner, U. K. Fischer, T. Volkel, and V. Rheinberger, Angew. Makromol. Chem., 245, 155 (1997).

10. T. Oishi, Y.-K. Lee, A. Nakagawa, K. Onimura, and H. Tsutsumi, Polym. J., 33, 81 (2001).

11. C. H. Bamford, K. G. Al-Lamee, I. P. Middleton, J. Paprotny, and R. Carr, Bull. Soc. Chim. Belg., 99, 919 (1990).

12. Y. Kimitsuka, K. Iwata, and H. Suzuki, Jpn. Kokai Tokkyo Koho JP 6-308108 (Nov. 4, 1994).

13. Y. K. Lee, K. Onimura, H. Tsutsumi, and T. Oishi, J. Polym. Sci., Part A: Polym. Chem., 38, 4315 (2000).

14. T. Otsu and M. Kinoshita, "Koubunshigousei Jikkenhou", Kagaku-dojin Publishing CO., Ltd., Kyoto, Japan, 1972, pp 69 $-91$.

15. Y. Okamoto, S. Honda, I. Okamoto, and H. Yuki, J. Am. Chem. Soc., 103, 6971 (1981).

16. Y. Okamoto, E. Yashima, M. Ishihara, and K. Hatada, Bull. Chem. Soc. Jpn., 61, 255 (1988).

17. F. Tüdös, T. Kelen, T. Foldes-Berezsnich, and B. Turcsanyi, J. Macromol. Sci., Chem., A 10, 1513 (1976). The monomer reactivity rations were determined by the method 6 described in this paper.

18. T. Jr. Alfrey and C. C. Price, J. Polym. Sci., 2, 101 (1947).

19. H. J. Harwood and W. M. Ritchey, J. Polym. Sci., Polym. Lett. Ed., 2, 601 (1964).

20. M. Kurokawa, H. Yamaguchi, and Y. Minoura, J. Polym. Sci., Polym. Ed., 17, 2241 (1979).

21. R. N. Majumdar, C. Carlini, and C. Bertucci, Makromol. Chem., 183, 2047 (1982). 